Article

\title{
Dependent, Deprived or Deviant? The Case of Single Mothers in Denmark
}

\author{
Martin Bak Jørgensen \\ Department of Culture and Global Studies, Aalborg University, 9220 Aalborg $\varnothing$, Denmark; E-Mail: martinjo@cgs.aau.dk
}

Submitted: 23 February 2018 | Accepted: 19 August 2018 | Published: 28 September 2018

\begin{abstract}
The article explores how categories of deserving and undeserving groups are established in policy designs and how social target groups are constructed according to such distinctions. Institutionalised systems of exclusion and inclusion have a profound impact on citizenship and substantial democracy. Neoliberalist political ideas and attitudes have strengthened the focus on deserving and undeserving groups over the last years and spurred a popular belief that welfare fraud is rampant. This tendency has led to a retrenchment of established rights and increasing use of illiberal means to further punish the undeserving. This article discusses these issues further by looking at the position of lone mothers in Denmark and how they constitute a social target group defined by their class, gender, ethnic, and religious differences. Categories of deservingness are also framed in national narratives and politics of belonging.
\end{abstract}

\section{Keywords}

Denmark; deservingness; single mother; social exclusion; welfare state; women

\section{Issue}

This article is part of a multidisciplinary issue of Politics and Governance.

(C) 2018 by the author; licensee Cogitatio (Lisbon, Portugal). This article is licensed under a Creative Commons Attribution 4.0 International License (CC BY).

\section{Introduction}

Welfare institutions and the general public have over the last centuries distinguished between those who deserve assistance and those who do not (Gans, 1995). The categories of deserving groups and criteria needed to define these are always situated in a political context. Feminist scholars have identified intersections between nationalism, gender, and welfare (Siim \& Stoltz, 2013; YuvalDavis, 2011). Migration scholars claim that immigrants as a group have become 'the new undeserving poor' in the European welfare states (Bommes \& Geddes, 2000; Jørgensen \& Thomsen, 2018; van Oorschot, 2006). Categories of deservingness are constructed through policy target groups. Schneider and Ingram (1997) have drawn particular attention to the instrumental and symbolic messages that policy target group constructions convey. The argument of Ingram and Schneider is that the social construction of target groups which carry negative messages will undermine the quality of effective democracy. Such policy designs can discourage active citizenship: 'Policies impact citizenship because they can encourage and facilitate participation for some, but discour- age or exclude participation by others' (Schneider \& Ingram, 2005, p. 27).

This article is interested in the 'others' in this statement. The article investigates how categories of deserving and undeserving groups are established in policy designs of entitlements for single providers. The article focuses especially on single mothers as a specific target group and analyses what position this target group has in the welfare system, how this is legitimized, and which policy tools are used in the management of this target group as well as the possible implications for citizenship and democracy. The article focuses on Denmark, especially the years 2010-2013, when single mothers were heavily debated in the media corresponding with the development and increased mandate of municipal control mechanisms. Single mothers are an illustrative group for understanding the restructuring of the welfare state and the shift in the categories of deserving and undeserving. Especially the changing emphasis on control in the neoliberal restructuring of the economy and institutions for understanding changes in social welfare policies targeting single providers. Furthermore, it is argued that single mothers are a diverse group in which intersections 
between gender, ethnicity, and class influence the construction of the specific target groups, policy messages, and tools. Issues of equality and welfare are therefore influenced by the particular intersections of a variety of categories.

The argument is not that single mothers are the only disadvantaged or persecuted group (the unemployed for instance have faced similar cut-backs in rights and services and have likewise been targets for increased control) but the single mothers group makes the restructuring of the welfare state and the deepening of (social) inequalities visible and can, therefore, be used to identify the broader effects which stem from neoliberal restructuring of the welfare state. This article presents the argument that people's belief that social fraud is rampant, despite the lack of empirical evidence, has led to the development of policy design emphasising control and sanctions. Policy target groups are constructed as weak and dependent, which itself legitimizes the policy designs. Social benefits available to single mothers have been subject to much attention from municipalities, politicians at parliamentary level, and the media. One explanation is that they are overrepresented among recipients of social benefits. Another explanation is that municipalities have focused mostly on developing controlling policies in areas where they have the greatest economic incentive in revealing social fraud. This would include additional benefits to single providers but not, for instance, public pensions which are financed solely through the state (Socialog Integrationsministeriet, 2011). Yet, there is a belief among the municipalities that single providers and especially single mothers are the welfare area most prone to social fraud, although this is based on convictions and estimates rather than facts (KMD, 2011). My argument is that the policy designs following from these convictions are detrimental to equality and democracy. The article ends with an analysis claiming that the policy framework is biased against ethnic and religious minorities. The policy tools developed, and the underlying rationales supporting these, cannot only be explained as a 'fight' against social fraud but show how categories are intersected and the tools are 'culturalised' to deal with social problems believed to characterize ethnic minority mothers.

\section{Data and Design}

The empirical material, i.e., what constitutes the policies, encompasses legislative texts, rules and regulations and action plans about the issue on the national level, is supplemented by rules, regulations, and implementation guidelines at the municipal level. This also includes the guidelines for the so-called control units/groups working at the municipal level. Moreover, the empirical material includes reports and surveys conducted on social fraud, in general, to assess how, if at all, single providers are discussed in this material.

This data is supplemented by decisions (until end2017) made by the National Social Appeals Board (NSAB).
All principle decisions taken by the Board pertaining to single providers over the last 20 years were collected. Out of 37 decisions, 13 dealt specifically with single mothers. Ten of these decisions revoked the municipal decision to terminate social benefits. The inclusion of material from NSAB is important as it has been decisive for the policy development and represents a type of material which is often overlooked (see Chunn \& Gavigan, 2004, and Crookshanks, 2012, for comparable approaches).

In the analysis, the focus is mainly on the national framework. The national framework is interpreted and implemented differently by the municipalities which in many cases have been more restrictive than the national framework. I, therefore, include different examples from the Danish municipalities. To make the argument that the target group constructions can only be analysed properly using an intersectional perspective a number of cases have been which were taken up by the media. The article draws on Yuval-Davis' and Leslie McCall's approaches on intersectionalism (McCall, 2005; YuvalDavis, 2006). Both make a distinction between intracategorical and inter-categorical complexities. In practice, this implies taking categories of difference into the analysis to document relationships of inequality among social groups (McCall, 2005). Consequently, it is the relationships between categories which are of interest and how these particular relationships position the target group in the policy framework. Employing an intersectional perspective makes it possible to identify the 'neglected' groups - those "whose identity crosses the boundaries of traditionally constructed groups" (Dill, 2002 , p. 5). In the present article, this, for instance, leads to the focus on single mothers with an ethnic and religious minority background which turns out to be decisive for their position in the target group constructions.

\section{Redistribution, Policy Designs, Neoliberalism and Citizenship}

Welfare states are based on criteria regarding who is entitled to what. Likewise, there is a strong emphasis on citizens' duties and obligations. The literature on redistribution points to different principles for welfare distribution, e.g., merit, need, and equality. However, redistribution also is dependent on citizenship and identity (Korpi, 2003). Van Oorschot points to additional criteria for deservingness (2006). Besides need and merit, he points to control (the level of control over neediness, i.e., those with less control are more deserving), identity (the closer to us/the in-group, the more deserving), and attitude (the more grateful and compliant, the more deserving). Following these criteria, studies have shown that the unemployed are perceived as having less character, being less responsible and less trustworthy. Elderly people are generally perceived as most deserving, followed by sick or disabled people, while the unemployed are regarded as less deserving, with immigrants being the least deserving group (Jørgensen \& Thomsen, 2016, 
2018). Policy target groups are not static entities but may change over time and context. The category of single mothers/solo-support mothers has historically changed from being one of the 'most' deserving groups to being depicted as undeserving (Chunn \& Gavigan, 2004; Crookshanks, 2012). Deserving groups always face the risk of falling into the undeserving category. Due to an underlying assumption that the welfare states are challenged by people and groups who might be dependent but not deserving, governments have developed policies sanctioning and punishing the groups believed to be a burden. This is an understanding conveying a liberal-paternalist message which has become a key element of neoliberalism. That society is liberal and free at the top but restrictive, paternalist, and authoritarian at the bottom, to use Wacquant's way of putting it $(2009$, p. 8$)$. The flipside of this is a growing insecurity and new bases for exclusion creating new forms of marginalisation. Within this political logic, emphasising individual responsibility is hence a necessary tool for revitalising welfare societies. Labour market participation is not the only marker for distinguishing between the entitled and un-entitled.

\section{Degenerative Policy Designs}

Schneider and Ingram have offered a conceptual framework for understanding degenerative policy designs and analyse target group constructions. Public policies are the primary tool through which governments and policymakers inscribe, exploit, entrench, perpetuate or change such social constructions (Schneider \& Ingram, 2005, p. 5). Advantaged target populations have significant political power resources, enjoy positive social constructions, and are characterised as being deserving. Dependents are groups with less political power resources but are still constructed as deserving in a moral sense in spite of being regarded as helpless and in need of correction and discipline. Contenders have resources that compare to those of advantaged groups but are not regarded as deserving. Deviants constitute weak and powerless groups who are negatively constructed as undeserving and of no value for society. Burdens are oversubscribed and benefits undersubscribed for the undeserving groups and vice versa for the deserving groups. Differential treatment in welfare policies may reflect different considerations. These constructs also characterise how policies are implemented and with what kind of message.

\section{The Danish Welfare State}

The Danish welfare state has the characteristics of a social democratic/Scandinavian welfare state model with a high level of tax-based re-distribution organised by the state. Re-distribution targets all citizens. The principle of universalism gained stronghold with the Pension Reform of 1956, which was later followed by universality in relation to social policies as social security, health, and education. Universalism aims at reducing social inequality, and although this aim has been challenged and transformed, decades later this goal of creating equal opportunities for all is perceived as instrumental for maintaining a socially coherent welfare society (Kristensen, 2007). As Kristensen argues although the universal welfare principles, such as the principle of universalism, are often based on an incomplete understanding of the citizen, in Denmark women are in general terms included in the notion of the implicit Danish citizen (Kristensen, 2007, p. 57). The ideal citizen can thus be said to be a working, able-bodied family member. The model presumes a high employment-rate, which succeeding governments have tried to foster through an active labour market policy. Migrants, therefore, become a test for the limits and sustainability of the welfare state if they face difficulties in entering the labour market.

\section{Single Mothers: Strong, Deprived or Deviant?}

In the following, focus will be on the construction of a particular target group: single mothers. The present article places itself within studies exploring problem representations and the role of public policy in relation to single mothers (Dwyer, 2004). These studies argue that individuals' choices are shaped and defined through political discourses based on individualisation, paternalism, and neoliberalism formulated through welfare-to-work programs and moral correctives (Gazso, 2009). Dwyer argues that 'rights are conditional on the acceptance of individual responsibilities' (2004, p. 282). Individual responsibilities are market responsibilities, hence the role as an informal caregiver is basically considered without value if a person claims social benefits (Gazso, 2009, p. 12). These studies argue that single mothers have gone from being dependent (and rightfully deserving) and/or deprived to now being deviant (Chunn \& Gavigan, 2004; Crookshanks, 2012; Mokhtar \& Platt, 2009; Swan, Shaw, Cullity, Hapern, \& Humphrey, 2008). Most empirical studies, also comparative studies, stem from the English-speaking countries, especially the US and UK, so how do these findings resonate in a Danish context? The Danish welfare state model has been described as women-friendly and not leading to the marginalisation of single mothers (Siim, 1999). In a Danish context, research has rejected that single mothers are represented as a societal problem (Siim, 1999; Stoltz, 1997). Siim argues that 'lone mothers have not been singled out as an ideological problem or as a political issue' $(1999$, p. 3). On the contrary, they are framed in a cultural image as being 'strong and autonomous group' (Siim, 1999, p. 142). These descriptions seem valid for their time but at the same time, this article will argue that single mothers have indeed been problematized in recent years as a consequence of the deepening and embedment of the neoliberal political rationale and the subsequent restructuring of the economy, institutions and policy logics. This is especially visible when the target group of single mothers intersects with categories of ethnicity and religion. 
As studies on intersectionalism have shown, the intersection of different categories construct different positions in society (Crenshaw, 1989; McCall, 2005; YuvalDavis, 2011). Gazco, for instance, shows that non-white single mothers in both Canada and Britain are likely to be poorer than others (Gazso, 2009). Labour market segregation is affected by both gender and race/ethnicity. The image of the black welfare has a very long history from the 'lazy promiscuous Jezebel' figure from the past to the US food-stamp moms of today. These images are very persistent; even today images of black mothers evoke hostile attitudes to welfare support (Gustafson, 2011; Pulkingham, Fuller, \& Kershaw, 2010). Although race as a category is less prominent in Denmark than in the US (and the UK) the same dynamics are nevertheless present (Albrekt Larsen \& Dejgaard, 2012). Ethnic minority background is decisive for public attitudes and eventually target group constructions. Racialisation of single mothers, however, is a dimension which has been given little research attention as most focus has been on gender (Mokhtar \& Platt, 2009). Adding a racial/ethnic dimension to the target group constructs makes it possible to show how characteristics are explicated. It shows how societal norms and expectations for behaviour are not colour-blind. If indeed the Danish welfare state model is gender neutral it is not neutral in terms of policy tools and rationales.

\section{Single Mothers in Denmark: Some Facts}

The number of single parents has been rather stable over the last 25 years. In 1992 there were 138,068 persons registered as single parents out of a total of 754,682 families with children. Single here refers to all lone parents (i.e., divorced/separated, as well as single parenthood by choice). ${ }^{1} 116,388$ of the single parents were single mothers. By 2017 the number increased to 115,627 single mothers and 13,912 single fathers amounting to almost $22 \%$ of all families (Danmarks Statistik, 2018). The Danish welfare model (alongside the other Scandinavian countries) is often described as being women-friendly due to its high level of universalism and individualisation (Siim, 1999; Siim \& Stoltz, 2013). These numbers do not say anything about the single parents' position in society. A 2004 study of social exclusion in Denmark concluded that "single mothers are one of the most disadvantaged groups in the Danish society" (Larsen, 2004, p. 20). The most recent study on single mothers offers different conclusions: almost $20 \%$ of all single mothers are on social befits (CASA, 2013). Not all single mothers are marginalised of course (in terms of socio-economic position) but the report identifies those who are (in 2009 14\%) as being: young, having ethnic minority backgrounds (in 2009 14\% of all single mothers), not having vocational training, being outside the labour force, unemployed, within education and/or receiving social benefits.

\section{Target Groups: ‘Genuine Singles’ as a Target Group}

In Denmark, single parents are entitled to social benefits (ordinary and extra children support, housing support, and residual/free place in daycare institutions) to meet their additional expenses. If the other parent not having the child living with him/her is not able to pay the stipulated contribution, an additional support (special child support) is available. It is a universal benefit available to all who meet the criteria, criteria which do not include means-testing. The key criterion for both types of special benefit is whether or not the applicant is 'genuinely single' (reelt enlig). This status according to the law has to be confirmed annually, although many municipalities require that the applicant sends in a form every month notifying them of any change in personal relations or income. The rules stipulating eligibility for social benefits as a single parent are in theory quite simple. If one parent has the custody of the child, and thereby most financial burdens, he/she is eligible for extra support.

In practice, the concept of "genuine single" is very hard to define and the criteria are indeterminate making it difficult for the municipalities to assess whether a person is single or not (Den Social Retshjælp, 2013; KL, 2008a; Social- og Integrationsministeriet, 2012). In reality, there are no fixed guidelines. It is not specified explicitly anywhere how long time a client can spend together with an ex-partner and still be considered single and entitled to extra benefits. The administrative practices are described in a handbook by Local Government Denmark which is meant to assist the municipalities (KL, $2008 b)$. In practice, the guidelines are stipulated legally following three cases dealt with by the NSAB in 1999. The decision and the dissemination of this are crucial, as it states that 'that there should not be proper evidence that there is a marital-like relationship' in order to terminate the social assistance and demand that assistance is paid back (Den Sociale Ankestyrelse, 1999, p. 1). Consequently, the municipalities have only to render it probable that a person is claiming benefits that he/she is not entitled to. Due to insecurity and confusion-and most likely the later decisions from the NSAB-the Ministry of Social Affairs and Integration published in July 2013 a pamphlet informing single providers about their rights and more explicitly what they cannot do (Social- og Integrationsministeriet, 2013).

\section{The Rationale for a Restrictive Turn}

The problem with these targeted social benefits is that they go hand in hand with distrust and increased control. Distrust is institutionalised and implemented in various control systems as the municipal control units are granted substantial power to pursue their task and ultimately legitimise the distrust itself. This assumption that

\footnotetext{
${ }^{1}$ The current debate on Single Mothers by Choice (SMC) or choice mothers is of a different nature and less relevant for this analysis, although the felt stigmatization of being a single mother may be more or less the same. The difference is that the SMC's are often resourceful and not unemployed nor are they accused of social fraud and hence do not fit into the target populations constructed by the public policies I am looking at.
} 
social fraud is increasing is the basis of many of the recent changes and policy actions which have been undertaken in recent years. There is no empirical evidence for either the proportion of social fraud itself or evidence indicating that it is growing. In the guidelines from 2008, Local Government Denmark writes that 'although we at the moment do not know if there is a real increase in the number of social fraud cases, more municipalities believe that there is more organised social fraud' (KL, $2008 \mathrm{~b}$, p. 41). This is in line with Gustafson's findings from a US context (Gustafson, 2011). A report from a 'transversal ministerial committee on better control' concluded that there is no information about nor valid estimates of the total abuse of social benefits but estimates suggest 91 municipalities made claims for back payment amounting to $€ 6.7$ million (Tværministerielt udvalg om bedre control, 2010, p. 17). The total amount spent on social benefits in Denmark was approximately $€ 32$ billion in 2010 (SFI, 2011, p. 7). In comparison, the committee estimates the value of moonlighting to amount to $€ 2,8$ billion (SFI, 2011, p. 25). Yet, the proposal of the committee is to increase the control of social fraud especially targeting genuine singles in particular. Similarly, the newspapers are full of stories of potential gains for the municipalities in uncovering social fraud (e.g., DR1, 2013; TV2 Øst, 2010). These stories have the single mother at the centre and most complaints municipalities receive deal with single mothers. In a report on the municipal decisions to terminate social benefits to single parents, the State Administration found that $49 \%$ of the decisions were directly wrong and later revoked, that in $26 \%$ of the cases the basis for the decision was weakly documented, and not documented at all in $23 \%$ of the cases (Statsforvaltningen Sjælland, 2011, p. 2).

Nevertheless, the overall message repeated by state authorities is of social fraud being a growing phenomenon and that increased control is the solution. Especially the category of genuine singles, i.e., single parents is identified as a target group. As the gender distribution mentioned above shows it is, in reality, a construction of single mothers. In 2008, the municipalities were requested to introduce more control and strengthen the effort against social fraud by the now abolished Ministry of Welfare (Ministerialtidende, 2009). The same message was repeated in 2011 with a new political agreement on strengthened efforts against social fraud (Regeringen, 2011). The logic of the agreement is that more people are taking advantage of the system undermining the social trust upon which the welfare state is built. Yet, there are no data supporting that there is more social fraud, that despite an extreme growth in anonymous tip-offs, or any evidence to support the claim that single mothers cheat more than others.

\section{Tools and Rules: Controlling Policies in Practice}

All municipalities are obliged to establish so-called control teams as well as the ability for citizens to submit sus- picions and accusations of social fraud anonymously. Today, $97 \%$ of all municipalities have control units (KMD, 2011). These are used to gather data used in the cases against individual clients. The tools used by these control units could be monitoring a client's house to see who visits and how frequently, to see if shoes belonging to a man are left outside the door during the night, if anyone borrows the car, or to investigate transactions and transfers in a bank account. In some cases, the control unit monitored Facebook profiles and even created false profiles to be able to interact with a given target and keep track of updates regarding their social life (Gaardmand, 2011a; Gaardmand \& Gjerding, 2011). This is an extreme case of surveillance and one which has dubious results. In 2011, NSAB revoked one such case. Sascha had been monitored for more than a year and was not informed about this until 11 months after the investigation was initiated by the control group. During some periods the control units passed by her home on a daily basis to observe (Gaardmand, 2011c). They looked for shoes belonging to a man and scrutinised her Facebook profile. One of the findings leading to the decision to revoke her social benefits was on the grounds that she was believed to live together with her ex-boyfriend and father of her children because that he had tagged a photo of Sascha and her sister with the comment 'nice women'. Most often these tips come from other citizens and are given anonymously. $47 \%$ of the municipalities answered that most cases involving social fraud were taken up following anonymous tip-offs (KMD, 2011, p. 18). In Aarhus, the city council employed pensioned police officers to undertake the control as they 'knew how to do efficient surveillance' (Gaardmand, 2011b). As the municipalities do not need any hard evidence to make a case but only render it probable that a client is committing social fraud all these different types of tools are used to do exactly that. In this case, the sanctions and burdens are heavily oversubscribed compared to the tools used regarding other groups, eg control of the working conditions of aupairs or the use of tax havens to avoid taxes.

Although the Ministry of Internal Affairs previously declared that there is no legal basis for making systematic observations and that all citizens have to be informed about on-going investigations and the gathering of information (KL, 2008a), this is exactly what happens and indeed what the Minister of Employment asks for in her response referred to above. The municipalities, according to the same declaration from the Ministry, employ the principle of proportionality. Monitoring Facebook profiles and surveillance techniques such as those outlined above definitely are out of proportion, but the means seem to serve the goal as the practices continue. The citizen has a right to know when a case is made and investigations are undertaken. Tools such as surveillance transgress the limits of the contracts and obligations and are not transparent for the citizen. It is legitimated by the municipalities through the construction of the target group of single mothers as one prone to cheating and 
not living up to the obligations and expectations of the 'good' citizen. As the citizen has the duty to disclose all material facts it is vital that citizens have the full information about the conditions and criteria but the notion of a genuine single is characterised by uncertainty and complexity and it is extremely difficult for this target group to know what their rights are. In some municipalities, single mothers are for instance informed that a boyfriend can sleep over a couple of times a week but cannot take out the trash or help with buying things (Gaardmand \& Gjerding, 2011). In other cases, the civil servant has told a social client if she could have sexual intercourse with her exhusband (Gaardmand \& Gjerding, 2011). Decisions transgressing the normal level of intimacy expected and tolerated from the communication with authorities and conveying a strong normative and paternalist message on how social clients should behave (cf., Chunn \& Gavigan, 2004; Crookshanks, 2012). This type of communication is only possible because the social client is constructed as a weak potentially undeserving recipient. The oversubscription of burdens and sanctions brings the system closer to the criminal system than the welfare system (cf., Gustafson, 2011; Wacquant, 2009).

The municipal decisions on withdrawing social benefit and initiating a case are based on administrative judgment but practice varies immensely between the municipalities. Scholars within law state that the evidence rarely is strong enough for the ordinary system of justice (Klingsey, Gaardmand, \& Gjerding, 2011). As already emphasised, neither is this necessary as the municipalities only have to render it probable. In other words, it is up to the discretion of the civil servant at work to decide if a social client should be accused of fraud. The aim rarely is to get the social client convicted in the criminal system but 'simply' to terminate the payment for undeserving groups. Even though the municipalities breach the law by systematically monitoring a social client, this carries no consequences for the control unit. Moreover, the data gathered through illegal means can still be used in cases against the client. Consequently, the legal protection characterising a liberal democracy is being undermined by illiberal and even illegal means.

The problem is not mentioned in a new agreement on better control from 2011. Indeed, the focus has been on creating extended remedies for the control groups, for instance, by making unannounced visits to a target's home. In 2010, control units from 80 municipalities made a demand for expanded remedies for control to the Ministry of Employment. In 2013, Udbetaling Danmark, an agency managing social benefit payments took over the responsibility for social fraud from the state. The agency can improve the linkage of records which is believed to increase control and uncover fraud. The aim is also to systematize the tools used by the municipalities who still have responsibility in cases where payments do not come from Udbetaling Danmark, e.g., social bene- fits to unemployed, reduced payment for child-care institutions, etc. The municipalities can still, and are encouraged to, use anonymous tip-offs (Social- og Integrationsministeriet, 2011). Although the agency launched a new 40 person task-force with the sole purpose of helping municipalities uncover social fraud, the control units demand more powers to use at the local level (KL, 2013). One such request is to be able to make surprise inspections, a tool currently only used by the police.

The policy tools are connected to social target groups. Single mothers have been a primary target group in the municipalities' endeavours to stop social fraud. Single mothers tipped-off are depicted as having irresponsible lifestyles, receiving large social benefits, giving birth to more children than they can support, and generally not meeting the norms of the middle class (e.g., Gaardmand \& Gjerding, 2011). Subsequently, they are a deviant group and not necessarily dependent, no matter how weak their position in society.

\section{Istahil, Laila, and Laily: Same but Different?}

The cases of Istahil, Laila, and Laily illustrate how ethnicity and religion intersect with the construction of a single provider. Istahil, Laila, and Laily are female Somali single providers who ended up accused of social fraud in their respective municipalities. Returning to the claims by Siim and Stoltz (2013) that single mothers have not been problematised, other researchers such as Bente Rosenbeck and Nina von Hielmcrone-who have both carried out research into single mothers-see the emergence of a new group of single mothers resembling the American welfare queen trope (in Gaardmand \& Gjerding, 2011). These stories are picked up from the media and are not individual analytical cases but examples of a particular target group construction. Having an ethnic minority background adds a cultural 'explanation' to an existing problem. This target group primarily lives in socalled ghettos and thereby reconfirms the government's problematisation of these urban areas. Again, there is no evidence that this group should be more inclined to social fraud than other single parents but the fact that ethnic minorities are overrepresented in the total recipients of social benefit ${ }^{2}$ not only legitimates harsh actions, oversubscription of control instruments and punishment, but at the same time disregards sociological explanations and structural inequality.

Single ethnic minority mothers tend to be in a particularly difficult situation as their language skills do not always allow them to understand their rights. Furthermore, their cases are not usually taken up in a positive manner in the media; when, in 2011, the newspaper Information did a series of articles on single mothers containing accusations of social fraud, none of the other media picked up the story until Sascha's previously mentioned case was described (cf., Section 10). The first three examples

\footnotetext{
${ }^{2}$ According to Albrekt Larsen and Dejgaard (2012) ethnic minorities received $28 \%$ of all social benefits in 2008 although constituting less than $10 \%$ of the population.
} 
were Somali women (Istahil, Laila, and Laily) but Sascha was a young majority Dane and was invited onto Danish TV. According to the producer, the Somali women were not fit for national broadcasting as 'Muslims are difficult to propagate' (Gaardmand \& Gjerding, 2011). As Schneider and Ingram argue, not all groups have equal access to participation and mobilisation (Schneider \& Ingram, 2005, p. 21). Having an ethnic minority backgroundand in many cases, another religious background-leads to peculiar, and in fact, degenerative policy designs and tools. Many single mothers end up losing their social benefits due to their ex-husband not having volatile housing conditions, e.g., not having a proper flat, staying in different places, or even being homeless. Often the control groups and civil servants have used this as evidence to suggest that the man must be living with the ex-partner. Somali men, in particular, have difficulties accepting divorces and the loss of authority, and for some it leads to a rather unstable lifestyle which ends up damaging the ex-partner without that being the intention (see Nauja Kleist in Gaardmand, 2011d). Although it ought to be fairly easy to investigate this, the cases show that despite the women telling the authorities that they are indeed living on their own, the women's own statements are disregarded, and they lose their entitlements (Gaardmand \& Gjerding, 2011). In some cases, it is almost absurd such as in the case of Laila where her ex-husband lived in Ukraine and yet the control group decided that she should lose her social benefits (Gaardmand, 2011d). The citizen's advisor in Holbæk municipality stated that the majority of single mothers experiencing problems resulting from the vaguely defined 'genuine single' have an ethnic minority background (Fasmer, 2011a). Sometimes this leads to the loss of social benefits and in other cases withdrawal from society to avoid losing their benefits. Holbæk is interesting as it has made decisions on stopping social benefits and demanding back-payment in a number of cases targeting Muslim single mothers. The control unit has here used the statements from an Imam, regarding difficulties of obtaining a divorce for the female part according to Sharia, to make the case that the social client was living in a marital-like relationship (Fasmer, 2011b; Gaardmand, 2011d). The statements came from a meeting that the control group in Odense, a large Danish municipality, had with a local Imam which then was spread to other municipalities and was used in training program for municipal control units. Obviously, these very general statements could be taken for what they are: anon-recognized religious actor expressing his own religious beliefs. Sharia-law is neither recognized by Danish law nor can it be used to build a case against a social client. Nonetheless, that is exactly what has happened in different municipalities. The statements by the Imam have been used to render it probable that Muslim single mothers were indeed not living on their own, as for instance happened in Laily's case. The leader of a municipal control group argues that although the religious criteria cannot be used solely as evidence:
We here are dealing with a group of citizens who in other situations makes claims based on having a special religion which demands they are offered affirmative actions" and "if their religion is that important in other situations then you cannot show up and say that in this case, my religion does not matter. (Gaardmand, 2011d)

Consequently, single Muslim mothers are constructed in a way as to make it impossible to leave a dysfunctional marriage and still share some common obligations with the ex-husband as having any contact would be taken as a proof of social fraud. NSAB has reversed all cases it has received based on the Imam's statement but it can only do so with the cases the Board actually receives. Only the most resourceful women and those assisted by lawyers and lay representatives know what to do and Muslim lone mothers are a marginalized group who frequently have lower language skills, hence the revoked cases may not change anything unless the practice is changed by law by the state authorities.

\section{Conclusions}

Responsiveness to public preferences is considered to be central for policy-making. As the analysis has shown it does not follow that responsiveness improves democracy. The public perception that social fraud is rampant has not been supported empirically. Nevertheless, policymakers and politicians have developed policy designs emphasising control, sanctions, and punishment to overcome the problem of social fraud. The policy tools and rules target weak and dependent groups. The case of the single mothers in Denmark illustrates an example of degenerative policy design damaging democracy rather than improving it. The construction of deserving and undeserving groups is not a new invention, but a distinction which can be traced back to the establishment of the welfare state and social policies. The construction of single mothers as an undeserving group is a particular type of construction which also has its own history. Many of the women described are not aware of possibilities of-or channels for-complaint and end up accepting municipal decisions. The cases show that the NSAB have turned around many of the decisions of the municipality but it can only do so if a case is taken to the Board. Marginalisation of the women and the fact that they are not well informed as to their rights is a democratic problem and a problem for substantive citizenship (Crookshanks, 2012). Municipalities-supported and encouraged by the government-have created a framework where social clients, in reality, are guilty until proven otherwise as the municipalities only have to render it probable that the person in question is committing social fraud. Paradoxically, the information used in the cases is gathered illegally but nonetheless can still be used. If a local administration does not accept the explanation it has the right to terminate funding. The mu- 
nicipalities act as both the executive and judicial power in this matter. In all other situations and dealings with the authorities, the citizen has the duty to disclose all material facts which will affect their financial situation and entitlement to benefits and it is assumed that people will actually do so and in general are constructed as lawabiding citizens. Yet, in the case of single parents, they have to submit a signed document stating that they are indeed genuine singles to maintain the financial support. The message here is that this group of citizens is prone to committing fraud and has to be controlled. This is a powerful construction of a social target group which not only conveys a message of the perceived value of that group but also strips them of their established rights and separates them from the broader citizenry. Dismissing or ignoring structural conditions, socio-economic realities and how they influence marginalised people's lives has become a common strategy. Instead, the responsibility is placed on the individual. There are no political gains in challenging this message. The rather simplistic logic prevailing is that people should support themselves and contribute to the common good. As the statistics illustrate that most single parents are women the category of genuine single becomes gendered. Freedom, self-choice, and flexibility can, as Wacquant claims, be felt at the top but the same choices are not available at the bottom of society, where many single mothers are positioned and targeted through punitive, paternalist, and authoritarian policies and attitudes.

\section{Acknowledgements}

The author is grateful for the productive comments received from colleagues at Aalborg University to previous drafts of this article as well as to the comments from the anonymous reviewers and editors of this issue of Politics and Governance.

\section{Conflict of Interests}

The author declares no conflict of interests.

\section{References}

Albrekt Larsen, C., \& Dejgaard, T. (2012). The institutional logic of images of the poor and welfare recipientsA comparative study of British, Swedish and Danish newspapers (CCWS Working Paper no. 78). Aalborg: Aalborg University.

Bommes, M., \& Geddes, A. (2000). Immigration and welfare. Challenging the borders of the welfare state. London: Routledge.

CASA. (2013). Rapport om udsatte enlige mødre 2013 [Report on vulnerable single mothers 2013]. Copenhagen: Susi og Peter Robinsohns Fond.

Chunn, D. E., \& Gavigan, S. A. M. (2004). Welfare law, welfare fraud, and the moral regulation of the 'never deserving' poor. Social and Legal Studies, 13(2),
219-243.

Crenshaw, K. W. (1989). Demarginalizing the intersection of race and sex. Chicago: University of Chicago.

Crookshanks, R. (2012). Marginalization through a custom of deservingness: Sole-support mothers and welfare law in Canada. Appeal, 17, 97-109.

Danmarks Statistik. (2018). Husstande og familier 1. januar 2018 [Households and families January 1. 2018]. Copenhagen: Danmarks Statistik.

Den Social Retshjælp. (2013). Retrieved from http:// www.socialeretshjaelp.dk/Kommunernes-h\%C3\%A5 ndtering-af-sager-om-socialt-bedrageri.1172.aspx

Den Sociale Ankestyrelse. (1999). SM B-1-99 Afgørelse truffet af: Den Sociale Ankestyrelse [SM B-1-99 Decision made by National Social Appeals Board]. Copenhagen: Den Sociale Ankestyrelse.

Dill, B. T. (2002). Work at the intersection of race, and sex. Connections: Newsletter of the Consortium on Race, Gender, and Ethnicity, Fall, 5-7.

DR1. (2013). Aktion social bedrageri [Action social fraud]. Copenhagen: DR.

Dwyer, P. (2004). Understanding social citizenship: Themes and perspectives for policy and practice. Bristol: The Policy Press.

Fasmer, T. (2011a, February 15). Socialsager bekymrer borgervejleder [Social fraud cases worries citizens councellor]. Venstrebladet.

Fasmer, T. (2011b, October 28). Imam-ord spøger stadig [Imam ghost still haunts]. Venstrebladet.

Gaardmand, N. (2011a, November 15). Socialt bedrageri [Social fraud]. Information.

Gaardmand, N. (2011b, March 21). Kommuners kontrolgrupper overvåger borgere ulovligt [The municipal control units survey citizens illegally]. Information.

Gaardmand, N. (2011c, August 29). Enlig mor overvåget ulovligt i over et år [Single mum surveyed illegally for more than a year]. Information.

Gaardmand, N.(2011d, March 14). Sharialoven bliver brugt mod borgere i sociale sager [Sharia-law is being used against citizens in social cases]. Information.

Gaardmand, N., \& Gjerding, S. (2011, November 12). Skyldige indtil det modsatte er bevist [Guilty until proved otherwise]. Information.

Gans, H. J. (1995). The war against the poor. New York: BasicBooks.

Gazso, A. (2009). Individualization, citizenship, and low income lone mothers' caring "choices" in Canada and Great Britain: Gender, race, and class still matter. Paper presented at the Social Policy Association meetings, Edinburgh, June 2009.

Gustafson, K. S. (2011). Cheating welfare: Public Assistance and the criminalization of poverty. New York: New York University Press.

Jørgensen, M. B., \& Thomsen, T. L. (2016). Deservingness in the Danish context: Welfare chauvinism in times of crisis. Critical Social Policy, 36(3), 330-351.

Jørgensen, M. B., \& Thomsen, T. L. (2018). “Needed but undeserving": Contestations of entitlement in the 
Danish policy framework on migration and integration. In J. E. Fossum, R. Kastoryano, \& B. Siim, (Eds.), Diversity and contestations over nationalism in Europe and Canada (pp. 337-364). London: Palgrave Macmillan.

KL. (2008a). Kontrol med udbetaling af sociale ydelser. Helhedsorienteret sagsbehandling [Control with the payout of social benefits. Comprehensive case management]. Copenhagen: KL.

KL. (2008b). Håndbog om fremgangsmåden $i$ sager om misbrug af sociale ydelser [Handbook on the approach to cases of social fraud]. Copenhagen: KL.

KL. (2013). Kontrolgrupper ønsker flere beføjelser [Control units demand more competences]. Retrieved from http://www.kl.dk/menu/Kontrolgrupper-onsker -flere-befojelser1-id120918/?n=1

Klingsey, M., Gaardmand, N., \& Gjerding, S. (2011, November 12). Regeringen må sikre enlige mødres retsstilling [The government must secure the legal position of single mothers]. Information.

KMD. (2011). Socialt bedrageri i Danmark Omfang, adfærd og holdninger KMD Analyse [Social fraud in Denmark, scope, behaviour and attitudes]. Copenhagen: KMD.

Korpi, W. (2003). Welfare state regress in Western Europe: Politics, institutions, globalization, and Europeanization. Annual Review of Sociology, 29, 589-609.

Kristensen, C. J. (2007). Towards two-tier universalism? A discussion of the welfare principle. Journal of Social Sciences, 3(2), 52-59.

Larsen, J. E. (2004). Fattigdom og social eksklusion. Tendenser i Danmark over et kvart århundrede [Poverty and social exclusion. Tendencies in Denmark over a quater of a century]. Copenhagen: SFI.

McCall, L. (2005). The complexity of intersectionality. Signs, 30(3), 1771-1800.

Ministerialtidende. (2009). Vejledning til temarevision 2009-Indsats mod misbrug af sociale ydelser [Instruction to thematic revision 2009-Efforts against fraud of social benefits]. Copenhagen: Ministerialtidende.

Mokhtar, C., \& Platt, L. (2009). Lone mothers, ethnicity and welfare dynamics. Journal of Social Policy, 39(1), 95-118.

Pulkingham, J., Fuller, S., \& Kershaw, P. (2010). Lone motherhood, welfare reform and active citizen subjectivity. Critical Social Policy, 30(2), 267-291.

Regeringen. (2011). Aftale om en styrket indsats mod social bedrageri [Agreement on a strengthened effort on social fraud]. Copenhagen: Regeringen.

Schneider, A. L., \& Ingram, H. (1997). Policy design for democracy. Lawrence, KS: University Press of Kansas.

Schneider, A. L., \& Ingram, H. (2005). Introduction. In A. Schneider \& H. Ingram (Eds.), Public policy and the social construction of deservedness. Deserving and entitled: Social constructions and public policy (pp. 1-28). Albany, NY: State University of New York Press.
SFI. (2011). Socialt bedrageri-Et litteraturstudie [Social fraud-A literary review]. Copenhagen: SFI.

Siim, B. (1999). Dilemmas of citizenship in Denmark: Lone mothers between work and care (FREIA Working Paper no. 45). Aalborg: Aalborg University.

Siim, B., \& Stoltz, P. (2013). Nationalism, gender and welfare-The politics of gender equality in Scandinavia (FREIA Working Paper no. 84). Aalborg: Aalborg University.

Social- og Integrationsministeriet. (2011). Udbetaling Danmark og Social Bedrageri [Udbetaling Denmark and social fraud]. Copenhagen: Social- og Integrationsministeriet.

Social- og Integrationsministeriet. (2012). Hvornår er en pensionist enlig eller samlevende, og hvornår kan en forsørger modtage børnetilskud som enlig? [When is a pensioner single or cohabiting and when can a provider receive child benefit as genuine single?]. Copenhagen: Social- og Integrationsministeriet. Retrieved from http://www.sm.dk/ temaer/sociale-omraader/sociale-ydelser/hvornaarer-man-enlig-eller-samlevende/Sider/default.aspx

Social- og Integrationsministeriet. (2013). Enlig eller samlevende? Vejledning til enlige forsørgere, der modtager børnetilskud eller økonomisk fripladstilskud [Single or cohabiting? Guidance to single providers who receive child support or economic free space support]. Copenhagen: Social- og Integrationsministeriet.

Statsforvaltningen Sjælland. (2011). Kommunernes praksis i afgørelser om børnetilskud til enlige forsørgere [Municipal practices in decisions on child support to single providers]. Copenhagen: Statsforvaltningen Sjælland.

Stoltz, P. (1997). Single mothers and the dilemmas of universal social policies. Journal of Social Policy, 26(4), 425-443.

Swan, R., Shaw, L. L., Cullity, S., Hapern, J., \& Humphrey, J. (2008). The untold story of welfare fraud. Journal of Sociology and Social Welfare, 35(3), 133-152.

TV2 Øst. (2010, August 2). Enlige mødre har rekord i sager om socialt bedrageri [Single mothers have record in cases on social fraud]. TV2east.dk.

Tværministerielt udvalg om bedre kontrol. (2010). Rapport fra det tværministerielle udvalg om bedre kontrol-Anbefalinger og overvejelser [Report from transversal ministerial committee on better control-Recommendations and considerations]. Copenhagen: Tværministerielt udvalg om bedre kontrol.

Van Oorschot, W. (2006). Making the difference in social Europe: Deservingness perceptions among citizens of European welfare states. Journal of European Social Policy, 16(1), 23-42.

Wacquant, L. (2009). Punishing the poor. The neoliberal government of social insecurity. Durham, NC: Duke University Press.

Yuval-Davis, N. (2006). Intersectionality and feminist pol- 
itics. European Journal of Women's Studies, 13(3), 193-209.

Yuval-Davis, N. (2011). The politics of belonging-
Intersectional contestations. Thousand Oaks, CA: Sage Publications.

\section{About the Author}

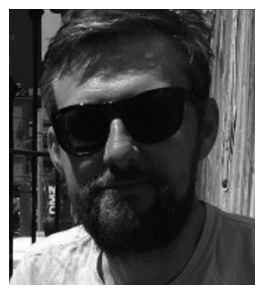

Martin Bak Jørgensen is Associate Professor in the Department for Culture and Global Studies at Aalborg University, Denmark. His main research areas include migration and integration policies, social movements, civil society and precarity. He has co-edited, with Carl-Ulrik Schierup, Politics of Precarity: Migrant Conditions, Struggles and Experiences (Brill, 2017), and, with Oscar Garcia Agustin, the books Solidarity without Borders. Gramscian Perspectives on Migration and Civil Society (Pluto Press, 2016) and Solidarity and the 'Refugee Crisis' in Europe (Palgrave, 2018). 